\title{
Effect of sildenafil citrate on interleukin-1 $\beta$-induced nitric oxide synthesis and iNOS expression in SW982 cells
}

\author{
Kyung-Ok Kim ${ }^{2}$, Shin-Young Park', \\ Chang-Woo Han ${ }^{3}$, Hyun Kee Chung ${ }^{3}$, \\ Dae-Hyun Ryu ${ }^{4}$ and Joong-Soo Han ${ }^{1,5}$
}

\author{
${ }^{1}$ Department of Biochemistry and Molecular Biology \\ College of Medicine, Hanyang University \\ Seoul 133-791, Korea \\ ${ }^{2}$ Department of Orthopaedics \\ Center for Musculoskeletal Research \\ University of Rochester Medical Center \\ New York 14642, USA \\ ${ }^{3}$ Department of Orthopedic Surgery \\ ${ }^{4}$ Department of Rheumatology \\ College of Medicine, Hanyang University \\ Seoul 133-791, Korea \\ ${ }^{5}$ Corresponding author: Tel, 82-2-2220-0623; \\ Fax, 82-2-2294-6270; E-mail, jshan@hanyang.ac.kr
}

Accepted 6 March 2007

Abbreviations: NO, nitric oxide; PDE5, phosphodiesterase 5

\begin{abstract}
The purpose of this study was to identify the effect of sildenafil citrate on IL-1 $\beta$-induced nitric oxide (NO) synthesis and iNOS expression in human synovial sarcoma SW982 cells. IL-1 $\beta$ stimulated the cells to generate NO in both dose- and time-dependent manners. The IL-1 $\beta$-induced NO synthesis was inhibited by guanylate cyclase (GC) inhibitor, LY83583. When the cells were treated with 8-bromo-cGMP, a hydrolyzable analog of cGMP, NO synthesis was increased upto 5 -fold without IL-1 $\beta$ treatment suggesting that cGMP is an essential component for increasing the NO synthesis. Synoviocytes and chondrocytes contain strong cGMP phosphodiesterase (PDE) activity, which has biochemical features of PDE5. When SW982 cells were pretreated with sildenafil citrate (Viagra), a PDE5 specific inhibitor, sildenafil citrate significantly inhibited IL-1 $\beta$-induced NO synthesis and iNOS expressions. From this result, we noticed that PDE5 activity is required for IL-1 $\beta$-induced NO synthesis and iNOS expressions in human synovial sarcoma cells, and sildenafil citrate may be able to suppress an inflammatory reaction of synovium through inhibition of NO synthesis and iNOS expression by cytokines.
\end{abstract}

Keywords: cyclic nucleotide phosphodiesterases, type 5 ; interleukin- $1 \beta$; nitric oxide; nitric oxide synthase type II; sildenafil

\section{Introduction}

Rheumatoid arthritis (RA) is a chronic inflammatory disease characterized by synovial hyperplasia and accumulation of inflammatory cells in inflamed joints (Harris, 1990; Jeong et al., 2004). Synovial cells are markedly activated by cytokines, adhesion molecules, and coagulation factors, resulting in hyperplasia of the synovial tissue (Nakayamada et al., 2005). These cells are major sources of several inflammatory cytokines such as IL-1, IL-6 and $T N F \alpha$, and they play crucial roles in the pathophysiology of RA (Firestein and Daye, 1990; Arend and Daye, 1995). IL-1 $\beta$ is one of the key $\mathrm{m}$ ediators involved in the pathogenesis of RA and is known to activate diverse intracellular signaling pathways. Although there are tissue-specific differences in the IL-1-activated signaling pathways, there are multiple IL-1-induced second messengers even in the same cell type that differentially regulate a subset of IL-1-responsive genes.

Nitric oxide (NO), a short-acting signaling bioactive free radical, is involved in many physiological and pathological processes (Schmidt and Walter, 1994). It is produced from L-arginine by NOS synthases (NOS) which are composed of three isoforms, including the constitutive endothelial (eNOS), neuronal (nNOS), and inducible isoforms (iNOS). Among the many cell lines in which eNOS and nNOS are constitutively presented, eNOS and nNOS are predominantly detected at the posttranscriptional level by calmodulin in a $\mathrm{Ca}^{2+}$-dependent manner. In contrast, iNOS, the cytokine-inducible form, can produce high levels of $\mathrm{NO}$ and is most commonly associated with inflammation in rheumatic disorders (Grabowski et al., 1997). IL-1 $\beta$-induced increase in the intracellular NO levels exerts direct effects on various cellular compartments (Veluthakal and Amin, 2004). An important function of $\mathrm{NO}$ is the activation of NO-sensitive guanylyl cyclase through its binding to the prosthetic heme group of the enzyme (Mullershausen et al., 2003). The activation of guanylyl cyclase (GC) leads to an enhanced conversion of GTP to the second messenger cGMP (cyclic guanosine monophosphate) resulting in an accumulation 
of intracellular cGMP (Koesling and Friebe, 1999). The role of increased cGMP levels in IL-1-induced gene expression and iNOS induction, as well as the downstream targets of cGMP, is well known (Geng et al., 1998).

In addition to cGMP formation, degradation of cGMP by cyclic nucleotide phosphodiesterases (PDEs) determines intracellular cGMP levels (Mullershausen et al., 2003). PDE isozymes differ in molecular structure, catalytic properties, intracellular regulation, location and sensitivity to selective inhibitors, as well as differential expression in various cell types (Corbin and Francis, 1999; Dousa, 1999; Juilfs et al., 1999; Soderling and Beavo, 2000). The major clinical applications of PDE inhibitors are as antithrombotics, antidepressants, anti-inflammatory agents, and bronchodilators (Hall, 1993). From our present results, we noticed that PDE 5 is one of the major PDE isozymes in human synovial cell line SW982. PDE 5 is the predominant enzyme responsible for cGMP hydrolysis in smooth muscle (Moreland et al., 1999) and platelets (Mullershausen et al., 2003). The activation of PDE 5 terminates NOinduced, cGMP-mediated smooth muscle relaxation, ultimately resulting in restoration of basal smooth muscle contractility (Juilfs et al., 1999).

Sildenafil citrate is a potent specific inhibitor of PDE 5, which ultimately increases intracellular cGMP concentration. PDE 5 inhibitors such as sildenafil (Viagra) and vardenafil (Levitra) have not only been shown to be effective in the treatment of erectile dysfunction, but they are also candidate drugs for cognition enhancement (Rutten et al., 2007). However, it is not clearly elucidated whether inhibition of the cGMP breakdown by sildenafil citrate has an affect on IL-1 $\beta$-induced NO synthesis or not. Therefore, in this study, we investigated the effect of sildenafil citrate, a specific inhibitor for PDE 5, on IL-1 $\beta$-induced NO synthesis and iNOS expressions.

\section{Materials and Methods}

\section{Reagents}

Recombinant human IL-1 $\beta$ was purchased from Calbiochem (San Diego CA) and MTT, LY83583, IBMX, 8-bromo-cGMP, dibutyryl cGMP ( $\left.\mathrm{Bt}_{2} \mathrm{CGMP}\right)$, 8-bromo-cAMP, 5'-GMP, N-(1-naphthyl) ethylenediamine dihydrochloride, sulfanilamide, $\beta$-actin antibody, and $\mathrm{H}_{3} \mathrm{PO}_{4}$ were from Sigma Chemical Co. (St. Louis, MO). Sildenafil citrate (Viagra: PDE type5 inhibitor) was obtained from Pfizer Pharmaceuticals, Inc. (New York, NY). The sources of the PDE inhibitors were; treqninsin (HL-725) and rolipram from Sigma (St. Louis, MO) and dipyridamole from
Calbiochem. Affinity-purified rabbit polyclonal antibody to iNOS was obtained from Santa Cruz Biotechnology (Santa Cruz, CA). The HRP-labeled second antibodies, enhanced chemiluminescence (ECL) detecting reagent, and cGMP enzymeimmunoassay kit were purchased from Amersham Pharmacia Biotechnologies, Inc. (Piscataway, NJ). All other chemicals were of analytical grade.

\section{Cell culture}

SW982, human synovial sarcoma cell line, was obtained from American Type Culture Collection (Rockville, MD). SW982 cells were grown in RPMI1640 (Gibco-BRL, Gaithersburg, MD), supplemented with $10 \%$ FBS (Gibco- BRL), $100 \mathrm{U} / \mathrm{ml}$ penicillin $\mathrm{G}$, and $100 \mu \mathrm{g} / \mathrm{ml}$ streptomycin sulfate, at $37^{\circ} \mathrm{C}$ in humidified $5 \% \quad \mathrm{CO}_{2}$ in air. Stock cultures were routinely subcultured at a cell density of $2 \times 10^{6}$ cells/dish once a week, and the medium was changed every 2 or 3 days.

\section{Nitrite analysis}

Since nitrite is the stable oxidation product of NO and accumulates in the medium, the production of NO was assessed by measuring the amount of nitrite accumulated in the culture supernatants, using a colorimetric reaction with the Griess reagent [0.1\% N-(1-naphthyl)ethylenediamine dihydrochloride, $1 \%$ sulfanilamide, and $2.5 \% \mathrm{H}_{3} \mathrm{PO}_{4}$ ]. Briefly, after stimulation for $48 \mathrm{~h}$, the culture supernatants were collected and mixed with equal volumes of the Griess reagent at room temperature for $10 \mathrm{~min}$. Absorbance at $550 \mathrm{~nm}$ was measured on a UV MAX kinetic microplate reader (Molecular Devices, Menlo Park, CA) and the concentration was deduced from a standard curve of sodium nitrite.

\section{Reverse transcriptase polymerase chain reaction}

Total cellular RNA was isolated using Trizol reagent (Life Technologies, Rockville, MD) according to the manufacturer's instructions. For the reverse transcriptase reaction, $5 \mu \mathrm{g}$ of total RNA was mixed with oligo $(\mathrm{dT})_{16}$ primer and Maloney murine leukemia virus (M-MLV) reverse transcriptase (Promega), and the mixture was incubated for $60 \mathrm{~min}$ at $42^{\circ} \mathrm{C}$. The transcribed products were mixed with each primer set and Taq DNA polymerase (Takara Shuzo), and then amplified according to the following amplification profiles; for iNOS, 40 cycles including denaturation for $30 \mathrm{~s}$ at $94^{\circ} \mathrm{C}$, annealing for $30 \mathrm{~s}$ at $61^{\circ} \mathrm{C}$, and extension for $30 \mathrm{~s}$ at $72^{\circ} \mathrm{C}$. The gene-specific primers used were iNOS (807 bp) forward, 5'CTGCAGTCTTCGATGGCCCGC-3', and reverse, 
5'-GTGAAACACGGGGGTGATGCT-3'. The PCR products were analyzed on a $1.2 \%$ agarose gel and visualized by ethidium bromide staining.

\section{Oligonucleotides}

Oligodeoxyribonucleotides specific for different PDE isozymes were synthesized according to sequences derived from GenBank entries of highly conserved catalytic or allosteric domains of PDE isozymes 1 to 9 (Table 1). Total RNA was reversetranscribed with M-MLV reverse transcriptase for $60 \mathrm{~min}$ at $42^{\circ} \mathrm{C}$. Reverse transcription reaction products were subjected to PCR with Taq DNA polymerase. PCR conditions were $94^{\circ} \mathrm{C}$ for $45 \mathrm{~s}, 62^{\circ} \mathrm{C}$ for $2 \mathrm{~min}$, and $72^{\circ} \mathrm{C}$ for $2 \mathrm{~min}$ for a total of 35 cycles. PCR products were analyzed on $1.2 \%$ agarose gel and visualized by ethidium bromide staining.

\section{Western blot analysis}

Confluent SW982 cells were incubated in a serumfree medium for $24 \mathrm{~h}$. The cells were stimulated

Table 1. Sequences of the different primers for PDE isozymes analysis.

\begin{tabular}{|c|c|}
\hline Oligonucleotides & Nucleotide sequence \\
\hline PDE1 (Forward) & 5'-AGCAAGTGGAGAGCATAGTCTG-3' \\
\hline (Reverse) & $\begin{array}{l}\text { 5' - TA G G G C CAT G G T C C A C C GAT- } \\
\text { AATG-3' }\end{array}$ \\
\hline PDE2 (Forward) & 5'-ACCGGTCTGTCAGTGAGATGGC-3' \\
\hline (Reverse) & $\begin{array}{l}\text { 5'-GAAGACAGCGTCTAATGCTGG- } \\
\text { TGT-3' }\end{array}$ \\
\hline PDE3 (Forward) & $\begin{array}{l}\text { 5'-TTCAACCAGTGATTCAGATTCTGA- } \\
\text { CAGTGG-3' }\end{array}$ \\
\hline (Reverse) & $\begin{array}{l}\text { 5'-CAGTACTAAGAGCAAAAGCTGCTTA- } \\
\text { GTTGG-3' }\end{array}$ \\
\hline PDE4 (Forward) & $\begin{array}{l}\text { 5'-TGCACTAGATGCAGTGTTCACGG- } \\
\text { A-3' }\end{array}$ \\
\hline (Reverse) & 5'-CAGAGCTTCCTCGACTCCTGACA-3' \\
\hline PDE5 (Forward) & 5'-ATGAGACTTCACTGCTGGAGAAC-3' \\
\hline (Reverse) & $\begin{array}{l}\text { 5'-ACAGTGCTGTTTCCAGGTCAGAC- } \\
\text { AG-3' }\end{array}$ \\
\hline PDE6 (Forward) & $\begin{array}{l}\text { 5'-TTTGTCGACGCTCTGTGCAAACA- } \\
\text { TCTCTTCT-3' }\end{array}$ \\
\hline (Reverse) & $\begin{array}{l}\text { 5'-AAATCTAGAACCTCCTCTGCTG- } \\
\text { TCACCT-3' }\end{array}$ \\
\hline PDE7 (Forward) & 5'-ACCATAACGCAGTCCACGCTGCG-3' \\
\hline (Reverse) & 5'-CTGTGTCTGGTGTCTTCTAGGCA-3' \\
\hline PDE8 (Forward) & $\begin{array}{l}\text { 5'-CAGCCAGAGACGACACTCTTC- } \\
\text { CAT-3' }\end{array}$ \\
\hline (Reverse) & $\begin{array}{l}\text { 5'-ATGATCTTAGCGTTGACTCGGA- } \\
\text { GC-3' }\end{array}$ \\
\hline PDE9 (Forward) & $\begin{array}{l}\text { 5'-CACTTGGCTGTCCTAGAGAAACG- } \\
\text { C-3' }\end{array}$ \\
\hline (Reverse) & $\begin{array}{l}\text { 5'-CTCCAGCGGTGAGATGTCATTG- } \\
\text { TA-3' }\end{array}$ \\
\hline
\end{tabular}

with or without IL-1 $\beta$. After the stimulation, the cells were quickly washed with ice-cold PBS and scraped in lysis buffer $(50 \mathrm{mM}$ Tris- $\mathrm{HCl}, \mathrm{pH} 7.5$, $150 \mathrm{mM} \mathrm{NaCl}, 1 \mathrm{mM} \mathrm{MgCl}$, $1 \mathrm{mM}$ EDTA, $1 \mathrm{mM}$ EGTA, 1 mM PMSF, 1\% Triton X-100, 0.5\% NP-40, $10 \mu \mathrm{g} / \mathrm{ml}$ aprotinin, and $10 \mu \mathrm{g} / \mathrm{ml}$ leupeptin) on ice. After sonication, the cell debris was removed by centrifugation $\left(14,000 \times \mathrm{g}\right.$ at $4^{\circ} \mathrm{C}$ for $\left.10 \mathrm{~min}\right)$, and the supernatants were used as cell lysate. An equal amount of protein $(20 \mu \mathrm{g})$ for each lysate was subjected to $7.5 \%$ SDS-PAGE for iNOS and then electrophoretically transferred onto nitrocellulose membrane. The membrane was incubated for $12 \mathrm{~h}$ at $4^{\circ} \mathrm{C}$ with anti-iNOS $(1: 250)$ antibody and then for $1 \mathrm{~h}$ with HRP-conjugated secondary antibody. Detection was carried out with the enhanced chemiluminescence (ECL: Amersham Pharmacia Biotech) system according to the manufacturer's protocol. Protein concentration was determined by the Bradford assay (Bio-Rad, Hercules, CA) with $\mathrm{BSA}$ as the standard.

\section{Statistical analysis}

The results are expressed as mean \pm S.E. values calculated from the specified numbers of determinations. Statistical significance was determined using one way ANOVA and considered to be significantly different at $P<0.001$.

\section{Results}

\section{Effect of IL-1 $\beta$ on NO synthesis and iNOS expressions in SW982 cells}

To investigate whether NO synthesis could be induced by IL-1 $\beta$ in human synovial sarcoma SW982 cells, the cells were treated with various concentrations of $1,5,10$, or $20 \mathrm{ng} / \mathrm{ml}$ of IL- $1 \beta$ for 12,24 , or $48 \mathrm{~h}$. The culture supernatants were assayed for the stable NO metabolite, nitrite. As shown in Figure $1 \mathrm{~A}, \mathrm{IL}-1 \beta$ stimulated SW982 cells to generate NO in a dose- and time-dependent manner. Maximum NO synthesis was observed at $20 \mathrm{ng} / \mathrm{ml}$ IL-1 $\beta$ concentration for $48 \mathrm{~h}$. Also, under our experimental conditions, we confirmed the expressions of iNOS mRNA and protein by $\mathrm{IL}-1 \beta$ in a dosedependent manner (Figure 1B).

\section{Effect of LY83583 on IL-1 $\beta$-induced NO synthesis in SW982 cells}

LY83583, an inhibitor of guanylate cyclase (GC), was used to investigate the role of CGMP in IL-1 $\beta$ induced NO synthesis. SW982 cells were pretreated with $0.5,1,5$, or $10 \mu \mathrm{M}$ of LY83583 for $30 \mathrm{~min}$, 
A

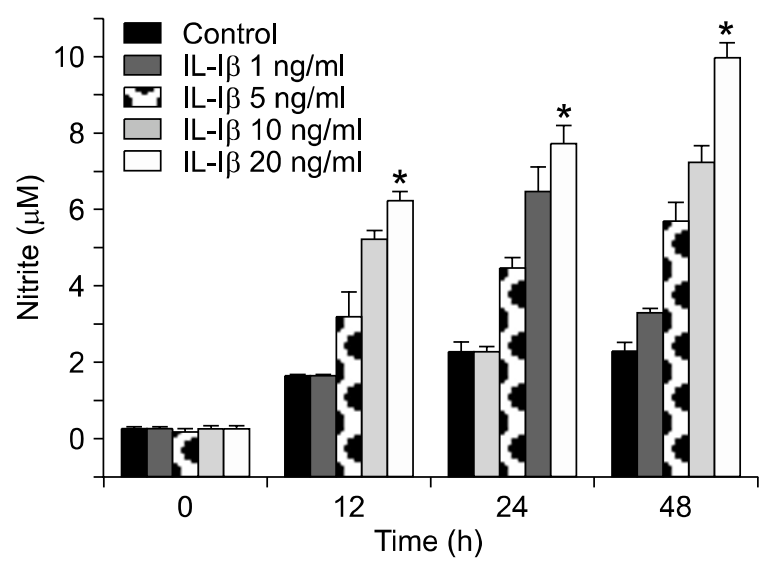

B

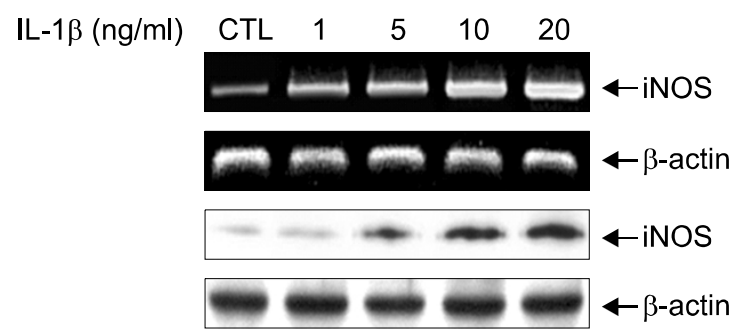

Figure 1. Effect of IL-1 $\beta$ on NO synthesis and iNOS protein expression in SW982 cells. SW982 cells were incubated with 1, 5, 10, and $20 \mathrm{ng} / \mathrm{ml}$ $\mathrm{IL}-1 \beta$ for 12,24 , and $48 \mathrm{~h}$, and their NO level was measured by estimating stable NO metabolite, nitrite, in conditioned medium by the Griess reaction. Results are expressed as mean values from three separate experiments performed in duplicate $(A)$. The cells were treated with 1,5 , 10 , and $20 \mathrm{ng} / \mathrm{ml} \mathrm{IL-1 \beta}$ for $6 \mathrm{~h}$, and the cells were harvested, and total RNA was isolated using Trizol reagent. RT-PCR analysis was performed using primers specific for human iNOS and $\beta$-actin. The cells' extract was examined after $48 \mathrm{~h}$, and were prepared and analyzed for iNOS protein expression by Western blot analysis. iNOS expression levels were shown to representatives of three independent experiments (B).

followed by treatment with IL-1 $\beta(20 \mathrm{ng} / \mathrm{ml})$. As shown in Figure 2, LY83583 significantly inhibited IL-1 $\beta$-induced NO synthesis by $64 \sim 75 \%$ dosedependently. Analysis by Western blot showed that LY83583 also reduced IL-1 $\beta$-induced iNOS protein expression.

\section{Effect of 8-bromo-cGMP on NO synthesis in SW982 cells}

When SW982 cells were treated with 10, 20, 100, or $500 \mu \mathrm{M}$ of 8-bromo-cGMP, a slowly hydrolyzable analog of cGMP, for $48 \mathrm{~h}$, NO synthesis was found to increase dose-dependently (Figure $3 \mathrm{~A}$ ), but not by a nonhydrolyzable analog, $\mathrm{Bt}_{2}$-cGMP nor 8-bromocAMP (Figure $3 \mathrm{~B}$ ). This result suggested that IL$1 \beta$-induced NO synthesis was most likely mediated through cGMP hydrolysis by cGMP-specific PDEs.

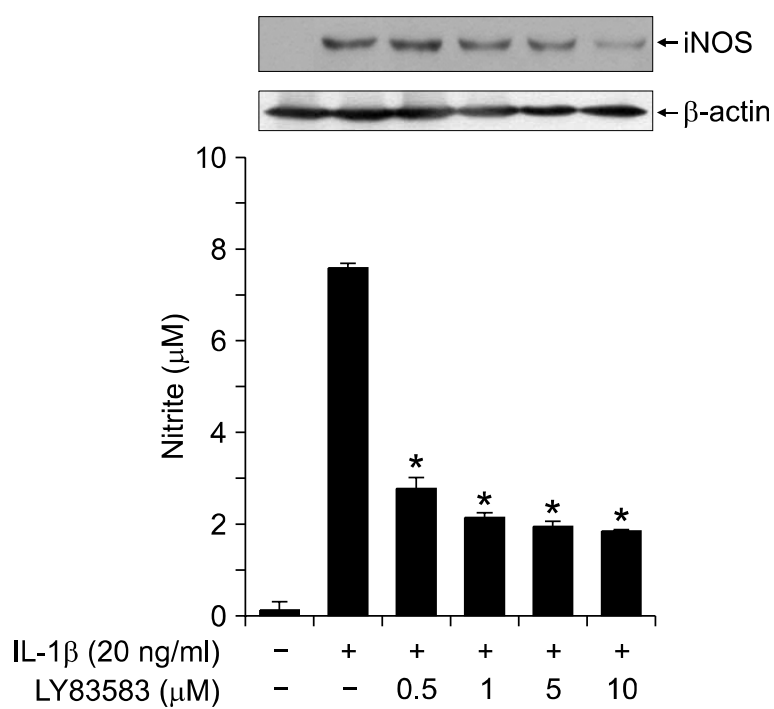

Figure 2. Effect of LY83583 on IL-1 $\beta$-induced NO synthesis in SW982 cells. SW982 cells were pretreated with $0.5,1,5$, and $10 \mu \mathrm{M} \mathrm{LY} 83583$ for $30 \mathrm{~min}$ and then treated with IL-1 $\beta(20 \mathrm{ng} / \mathrm{ml})$. After $48 \mathrm{~h}$, NO levels were determined in conditioned medium, and the protein expression of iNOS was assessed by Western blot analysis. Results represent means \pm S.E. from three separate experiments performed in duplicate. ${ }^{*} P<$ 0.001 , as compared to the control.

Next, we tried to find out which PDE isozymes are present in SW982 cells. Nine PDE isozymes were identified based on cDNA sequences and substrate specificity. As shown in Figure 3C, the mRNA expressions of PDE $1,3,4,6$, and 9 were not found, while PDE 2, 5, 7 and 8 mRNA were expressed in SW982 cells. Among the PDE isozymes expressed in SW982 cells, PDE2 is the cGMP-stimulated form and PDE 7 and 8 are cAMP-specific isozymes. Therefore PDE5 is the only isozyme which is responsible for cGMP hydrolysis in SW982 cells (Corbin and Francis, 1999; Dousa, 1999; Soderling and Beavo, 2000).

\section{Effect of PDE 5 inhibitor, sildenafil citrate on IL-1 $\beta$-induced NO synthesis and iNOS expression}

Sildenafil citrate, a selective reversible PDE 5 inhibitor, exhibits a high affinity for PDE 5 (Rutten et al., 2007). The effect of sildenafil citrate on NO synthesis in SW982 cells, which had been exposed to IL-1 $\beta$, was examined. Compared with the control, there was no significant difference in the trypan blue positive cell counts, when the cells were treated with up to $100 \mu \mathrm{M}$ of sildenafil citrate, indicating that the doses of the PDE 5 inhibitor used for $30 \mathrm{~min}$ or $1 \mathrm{~h}$ were not toxic to the cells (data not shown). Next, in order to examine the effect of sildenafil citrate on NO synthesis, SW982 cells were pretreated with $5,15,30$, or $50 \mu \mathrm{M}$ of 
A

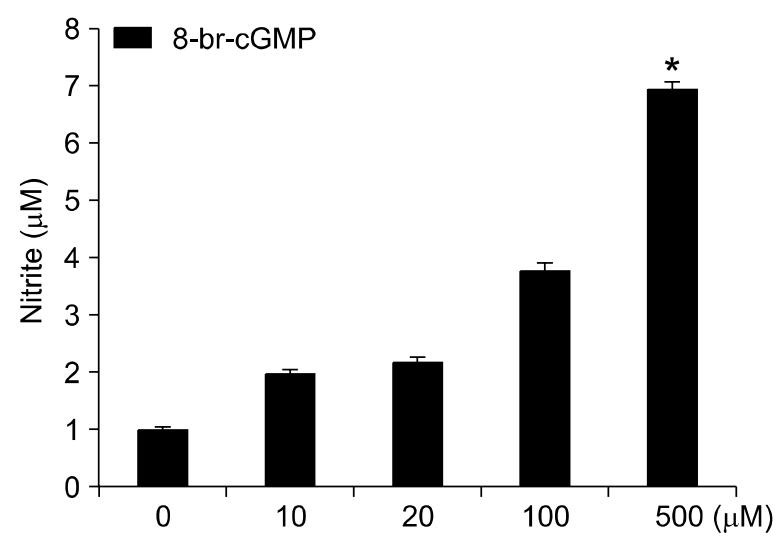

B

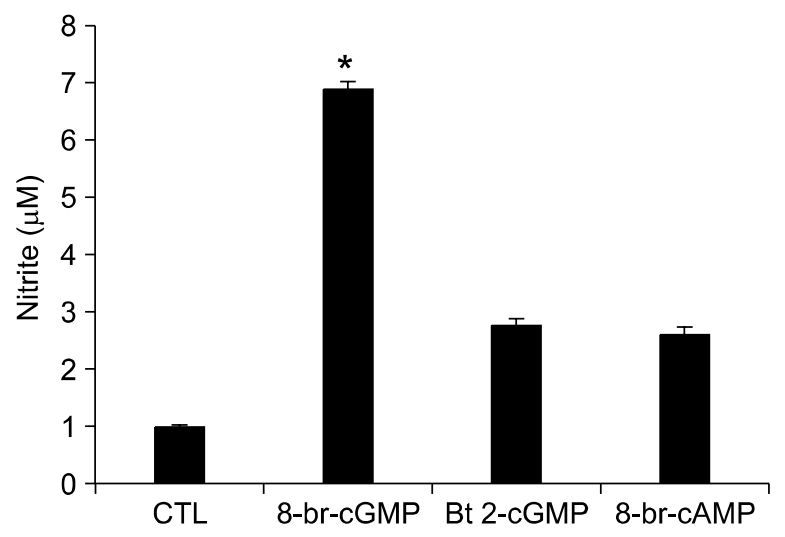

C

M PDE1 PDE2 PDE3 PDE4 PDE5 PDE6 PDE7 PDE8 PDE9

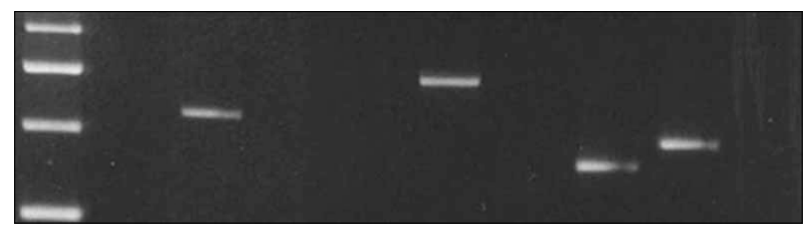

Figure 3. Effect of 8-bromo-cGMP on IL-1 $\beta$-induced NO synthesis in SW982 cells. SW982 cells were treated with a slowly hydrolyzable analog of cGMP, 8-bromo-cGMP at indicated doses (A), and were treated with $500 \mu \mathrm{M}$ each of 8-br-cGMP, Bt 2 -cGMP, and 8-br-cAMP (B). The NO level was measured by estimating the stable NO metabolite, nitrite, in medium conditioned for $48 \mathrm{~h}$ by the Griess reaction. Results represent mean values from three separate experiments performed in duplicate. ${ }^{*} P<0.001$, as compared to the control. Expression of different PDE isozymes mRNA was analyzed from endogenous SW982 cells by RT-PCR using different-specific primers (C). Aliquots of the reaction mixtures containing oligonucleotides specific for particular PDE isozymes were drawn after 35 cycles and analyzed on an agarose-gel stained with ethidium bromide.

sildenafil citrate for $1 \mathrm{~h}$, and then treated with IL-1 $\beta$ $(20 \mathrm{ng} / \mathrm{ml})$. As seen in Figure 4A, NO synthesis was inhibited from $51 \%$ up to $75 \%$ by pretreatment of sildenafil citrate. Another PDE 5 inhibitor, dipyridamole, also suppressed IL-1 $\beta$-induced NO synthesis showing similarity with sildenafil citrate. However, a PDE 4 inhibitor, rolipram, could not suppress NO synthesis effectively (Figure 4B). Concomitant with decreased NO synthesis after pretreatment with sildenafil citrate, IL-1 $\beta$-induced mRNA and protein expressions of iNOS were also decreased (Figure 4C), demonstrating that PDE 5 is the key enzyme for cGMP-induced NO synthesis and iNOS expression in SW982 cells. $500 \mu \mathrm{M}$ of IBMX, nonisozyme specific PDE inhibitor, was used as a control.

\section{Discussion}

Nitric oxide (NO) is a multifunctional mediator produced by various cells and participates in inflammation and autoimmune-mediated tissue destruction
(Bredet and Snyder, 1994). NO levels are increased in synovial fluid in rheumatoid arthritis (RA), and synoviocytes and chondrocytes are thought to be primary producers of NO (Sakurai et al., 1995; Grabowski et al., 1996). NO, which has emerged as an important proinflammatory mediator in the RA synovium (Mclnnes et al., 1996; Hilliquin et al., 1997), can modify protein function through nitrosylation of thiol groups. iNOS can produce high levels of NO and is most commonly associated with inflammation in rheumatic disorders (Grabowski et al., 1996). In the present study, we observed that IL-1 $\beta$ enhanced NO synthesis and iNOS expressions in human synovial sarcoma SW982 cells. The pathogenesis of osteoarthritis and RA has been associated with the presence of proinflammatory cytokines such as IL-1 and TNF- $\alpha$, which can induce production and synthesis of the mediators $\mathrm{NO}$ and prostaglandin E2 (LeGrand et al., 2001). Taken together, our data suggest that induction of iNOS in SW982 cells may be an important source of NO in RA resulting from inflammatory disorders. Also, elucidation of the molecular mechanism 
A

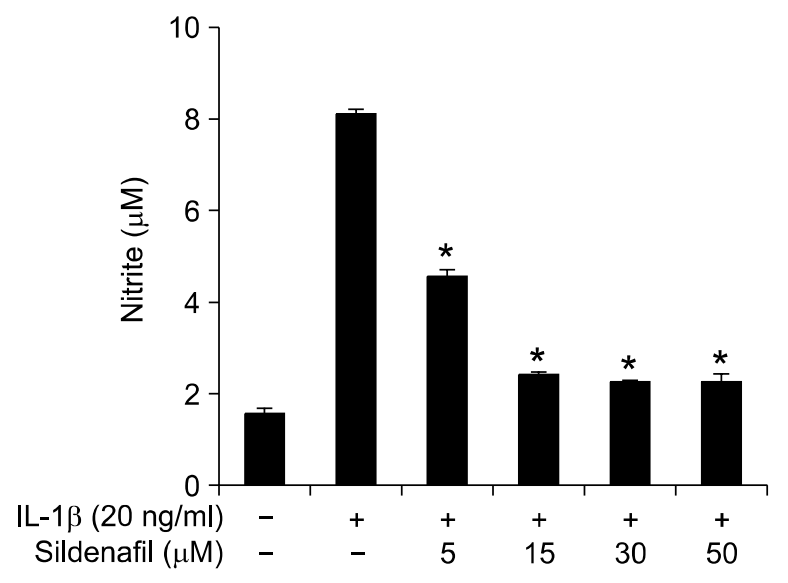

B

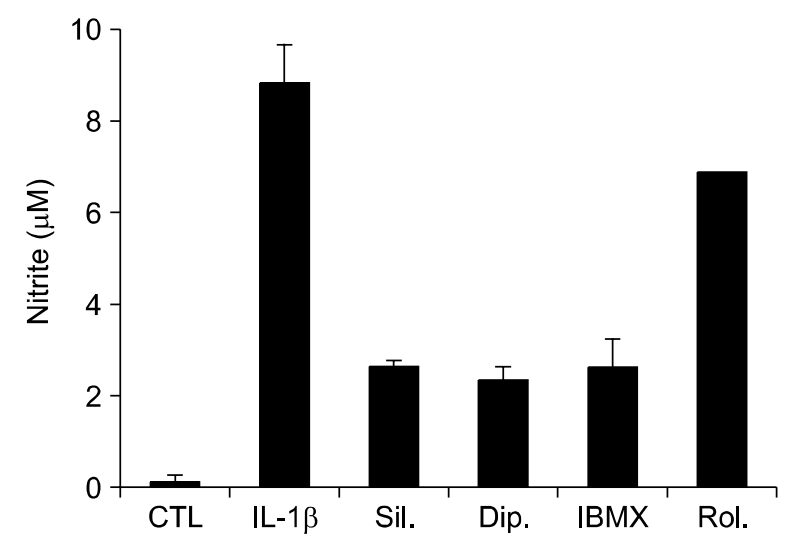

C

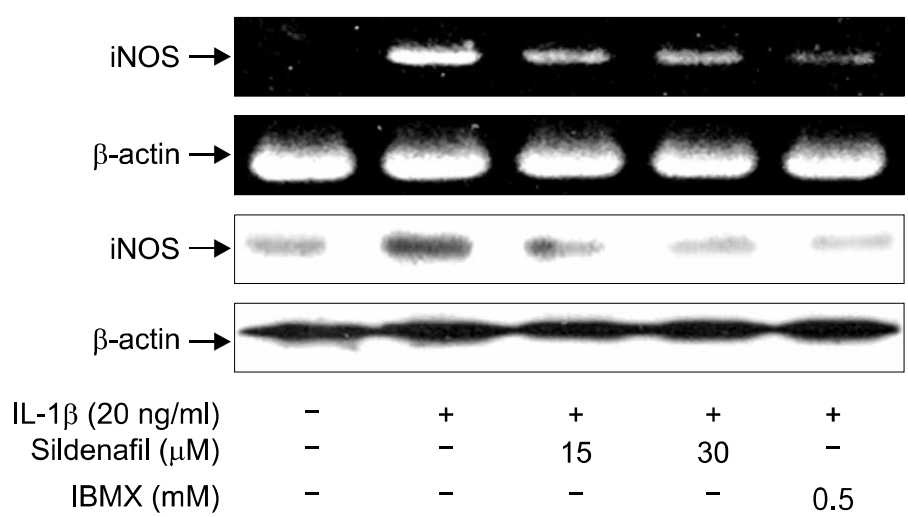

Figure 4. Effect of PDE 5 inhibitor, sildenafil citrate. SW982 cells were pretreated with $5,15,30$, and $50 \mu \mathrm{M}$ sildenafil citrate for $1 \mathrm{~h}$ and then stimulated with IL-1 $3(20 \mathrm{ng} / \mathrm{ml})$ for $48 \mathrm{~h}(\mathrm{~A})$. The cells were preincubated with the PDE inhibitors sildenafil citrate (Sil, $30 \mu \mathrm{M})$, dipyridamole (Dip, $30 \mu \mathrm{M})$, IBMX (500 $\mu \mathrm{M})$, and rolipram (Rol, $30 \mu \mathrm{M})$ for $1 \mathrm{~h}$, and then stimulated with $20 \mathrm{ng} / \mathrm{ml}$ of IL-1 $\beta$. NO levels were determined by estimating nitrite in medium conditioned for $48 \mathrm{~h}$ by the Griess reaction (B). The cells were pretreated with sildenafil citrate $(15 \mu \mathrm{M}$ and $30 \mu \mathrm{M})$ or $500 \mu \mathrm{M}$ IBMX for $1 \mathrm{~h}$ before treatment with 20 $\mathrm{ng} / \mathrm{ml} \mathrm{IL-1} \beta$ for $6 \mathrm{~h}$. The cells were harvested, and total RNA was isolated using Trizol reagent. RT- PCR analysis was performed using primers specific for human iNOS and $\beta$-actin. The PCR products were analyzed in $1.2 \%$ agarose-gel. The cells' extract were examined after $48 \mathrm{~h}$ and analyzed for iNOS protein expression by Western blot analysis. Results represent mean values from three separate experiments performed in duplicate. ${ }^{*} P<0.001$, as compared to the control.

involved in the regulation of iNOS expression by IL-1 $\beta$ might provide new insights into the pathophysiology of inflammation and may lead to new therapeutic strategies capable of interrupting the inflammatory cascade at key points.

Geng et al. (1998) reported that the IL-1 induction of NO synthesis, iNOS mRNA, and protein accumulation was prevented by LY83583 in human chondrocytes. LY83583, an inhibitor of guanylate cyclase (GC), inhibits IL-1 $1 \beta$-induced NO synthesis dose-dependently in SW982 cells indicating that cGMP, a product of GC, is important in NO synthesis. Several experimental observations suggest that particulate GC is involved in iNOS expression (Moro et al., 1996; Geng et al., 1998). To elucidate the role of cGMP in IL-1 $\beta$ activation in SW982 cells, we tested the cells with a hydrolyzable analog of cGMP, 8-bromo-cGMP, and this analog of cGMP also induced NO production dose-dependently, suggesting that NO synthesis could be affected by intracellular levels of cGMP.

In this study, we detected four different PDEs, PDE 2, 5, 7, and 8, that were present in SW982 cells. PDE 5 is strictly specific for cGMP-binding unlike the other three - PDE 2 (one of the main receptor targets for cGMP in some cGMP-mediated signal transduction mechanisms), PDE 7 (high affinity and selectivity for CAMP as a substrate), and PDE 8 (cAMP-hydrolyzing enzyme) (Hall,1993; Corbin and Francis, 1999; Dousa, 1999). Therefore, 
PDE5 is mainly involved in cGMP hydrolysis among the PDE isozymes, expressed in SW982 cells. Sildenafil citrate is known to selectively block PDE 5 , resulting in the inhibition of cGMP degradation in target tissues, and it causes an anxiogenic effect in the elevated plus maze in mice (Moreira et al., 2000; Kurt et al., 2001). Sildenafil citrate also shows a synergistic anxiogenic effect with the combination of NOS substrate L-arginine (Volke et al., 2003). However, the extent and impact of the central effects of sildenafil is not well understood on NO synthesis. One of the main targets in NO signaling is soluble guanylate cyclase (sGC). sGC converts GTP to an important intracellular signaling molecule cGMP. The principle mediator of cGMP signal is cGMP dependent protein kinase (PKG) (Riku et al., 2005). In gastric smooth muscle, cGMP-dependent PKG activates PDE 5 and inhibits GC activity, resulting in cGMP levels that are regulated by PKG-dependent activation of PDE 5 and PKG-specific inhibition of GC (Bredet and Snyder, 1994). Induction of gene expression by cyclic nucleotides via the activation of protein kinase has been well characterized (Moreland et al., 1999). This study addressed the role of PDE 5 activation through GC activation in IL-1 $\beta$ - induced NO synthesis and iNOS expression in SW982 cells. NO synthesis by $\mathrm{IL}-1 \beta$ and cGMP analog was suppressed by a PDE 5 inhibitor, sildenafil citrate, in SW982 cells, suggesting that PDE 5 acts as a key enzyme for IL-1 $\beta$ induced NO synthesis and iNOS expressions in SW982 cells, and sildenafil citrate, Viagra, can relieve an inflammatory reaction of the synovium through inhibition of NO synthesis induced by IL-1 $\beta$.

\section{Acknowledgements}

This work was supported by the Seoul R\&BD program (2005) and partly by a grant (2002) from Hanyang University.

\section{References}

Arend WP, Daye JM. Cytokines and cytokine inhibitor or antagonists in rheumatoid arthritis. Arthritis Rhuem 1995;38: 151-60

Bredet DS, Snyder SH. Nitric oxide; a physiological messenger molecule. Annul Rev Biochem 1994;63:175-95

Corbin JD, Francis SH. Cyclic GMP phosphodiesterase-5; target of Sildenafil. J Biol Chem 1999;274:13729-32

Dousa TP. Cyclic-3'-5'-nucleotide phosphodiesterase isozymes in cell biology and patho-physiology of the kidney. Kidney Int 1999;55:29-62
Firestein GS, Alvaro-Garcia JM, Maki R. Quanitative analysis of cytokine gene expression in rheumatoid Arthritis. J Immunol 1990;144:3347-53

Geng Y, Zhou L, Thompson WJ, Lotz M. Cyclic GMP and cGMP-binding phosphodiesterase are required for interleukin-1-induced nitric oxide synthesis in human articular chondrocytes. J Biol Chem 1998;273:27484-91

Grabowski PS, England AJ, Dykhuizen R, Copland M, Benjamin N, Reid DM, Ralston SH. Elevated nitric oxide production in rheumatoid arthritis. Arthritis Rheum 1996; 39:643-7

Grabowski PS, Wrigh PK, Van't Hof RJ, Helfrich MH, Ohshima H, Ralston SH. Immuno-localization of inducible nitric oxide synthase in synovium and cartilage in rheumatoid arthritis and osteoarthritis. Br J Rheumatol 1997;36:51-5

Hall IP. Multiple conformations of Phsophodiesterase-5. Br J Clin Pharmacol 1993;35:1-7

Harris ED. Rheumatoid arthritis. Pathophysiology and implications for therapy. N Engl J Med 1990;322:1277-89

Hilliquin P, Borderie D, Hernvann A, Menkes CJ, Ekindjian OG. Nitric oxide as S-nitrosoproteins in rheumatoid arthritis. Arthritis Rheum 1997;40:1512-7

Jeong JG, Kim JM, Cho H, Hahn W, Yu SS, Kim S. Effects of IL-1 $\beta$ on gene expression in human rheumatoid synovial fibroblasts. Biochem Biophy Res Commun 2004;324:3-7

Juilfs DM, Soderling S, Burns F, Beavo JA. Cyclic GMP as substrate and regulator of cyclic nucleotide phosphodiesterases (PDEs). Rev Physiol Biochem Pharmacol 1999;135: 67-104

Koesling D, Friebe A. Soluble guanylyl cyclase: structure and regulation. Rev Physiol Biochem Pharmacol 1999;135: 41-65

Kurt M, Bilge SS, Aksoz E, Kukula O, Celik S, Kesim Y. Effect of sildenafil on anxiety in the plus-maze test in mice. Pol J Pharmacol 2001;56:353-7

LeGrand A, Fermor B, Fink C, Pisetsky DS, Weinberg JB, Vail TP, Guilak F. Interleukin-1, tumor necrosis factor $\alpha$, and interleukin-17 synergistically up-regulate nitric oxides and prostaglandin E2 production in explants of human osteoarthritic knee menisci. Arthritis Rheum 2001;44:2078-83

Mclnnes IB, Leung BP, Field M, Wei XQ, Huang FP, Sturrock RD, Kinninmonth A, Weidner J, Mumford R, Liew FY. Production of nitric oxide in the synovial membrane of rheumatoid and osteoarthritis patients. J Exp Med 1996;184: 1519-24

Moreira SG Jr, brannigan RE, Spitz A, Orejuela FJ, Lipshultz LI, Kim ED. Side effect profile of sildenafil citrate (Viagra) in clinical practice. Urology 2000;56:474-6

Moreland RB, Goldsrein I, Kim NN, Traish A. Sildenafil citrate, a selective phosphodiesterase type 5 inhibitor: Research and clinical implications in erectile dysfunction. TEM 1999;10:97-104

Moro MA, Russel R, Cell S, Lizasoain I, Su Y, Darley-Usmar VM, Radomski MW, Moncada S. cGMP mediates the 
vascular and platelet actions of nitric oxide: confirmation using an inhibitor of the soluble guanylyl cyclase. Proc Natl Aca Sci USA 1996;93:1480-5

Mullershausen F, Friebe A, Feil R, Tompson WJ, Hofmann $F$, Koesling D. Direct activation of PDE5 by cGMP: long-term effects within NO/cGMP signaling. J Cell Biol 2003;160: $719-27$

Nakayamada S, Kurose H, Saito K, Mogami A, Tanaka Y. Small GTP-binding protein Rho-mediated signaling promotes proliferation of rheumatoid synovial fibroblasts. Arthritis Res Ther 2005;7:476-84

Riku K, Aleksi L, Hannu K, Eeva M. Nitric Oxide Production and Signaling in Inflammation. Curr Drug Targets Inflamm Allergy 2005;4:471-9

Rutten K, Prickaerts J, Hendrix M, Van der Staay FJ, Sik A Blokland A. Time-dependent involvement of cAMP and cGMP in consolidation of object memory: Studies using selective phosphodiesterase type 2, 4 and 5 inhibitors. Eur J Pharmacol 2007;558:107-12

Sakurai H, Kohsaka H, Liu MF, Higashiyama H, Hirata Y, Kanno K, Saito I, Miyasaka N. Nitric oxide production and inducible nitric oxide synthase expression in inflammatory arthritis. J Clin Invest 1995;96:2357-63

Schmidt HH, Walter U. NO at work. Cell 1994:78:919-25

Soderling SH, Beavo JA. Regulaion of cAMP and cGMP signaling; new phosphodiesterases and new functions. Curr Opin Cell Biol 2000;12:174-179

Veluthakal R, Amin R. Interleukin-1 beta induces posttranslational carboxylation and alterations in subnuclear distribution of lamin B in insulin-secreting RINm5F cells. Am J Physiol Cell Physiol 2004;287:1152-62

Volke V, Wegener G, Vasar E. Augmentation of the NO-cGMP cascade induces anxiogenic-like effect in mice. J Physiol Pharmacol 2003;54:653-60 